\title{
Opening Remarks
}

To start my opening remarks on the Asia-Pacific Symposium on Growth Hormone Research and Therapy, I would like to thank all of you so much for joining this meeting at such a busy time.

The symposium was designed to assist young Asian pediatric endocrinologists to have access to the most recent advances in the field of pediatric endocrinology and to have an opportunity to discuss their specific problems with our distinguished guest speakers. I am confident that you will find all the upcoming lectures to be exciting and useful as they cover up-to-date and wellselected topics including: an update on pediatric endocrinology; dwarfism due to mutation in the receptor for GHRH; human growth hormonal therapy update in Thailand; physical growth in the primate; the molecular basis of hypopituitarism; the role of the insulin-like growth factor system in the developing brain, and short stature caused by mutant $\mathrm{GH}$.

I am most grateful to the excellent guest speakers: Dr. MacGillivray, Dr. Gertner, Dr. Angsusingha, Dr. Iwamoto, Dr. Radovick, Dr. Werther, and Dr. Chihara. I am especially grateful to Dr. MacGillivray who made excellent suggestions for this symposium as the former president of the Wilkins Pediatric Endocrine Society.

Finally, I hope that this symposium will prove to be an excellent opportunity for friendship as we could all share and enjoy stimulating discussions with participants from abroad.

Nobutake Matsuo, Tokyo 